\title{
EVALUATION OF EFFICACY, RELIABILITY, AND TOLERABILITY OF SIBUTRAMINE IN OBESE PATIENTS, WITH AN ECHOCARDIOGRAPHIC STUDY
}

\author{
Alfredo Halpern, Claudia Cozer Leite, Nathan Herszkowicz, Alfonso Barbato \\ and Ana Paula Arruda Costa
}

RHCFAP/3077

HALPERN A et al. - Evaluation of efficacy, reliability, and tolerability of sibutramine in obese patients, with an echocardiographic study. Rev. Hosp. Clín. Fac. Med. S. Paulo 57(3): 2002.

This is a double-blind, placebo-controlled study of the efficacy, safety, and tolerability of sibutramine in the management of obese patients for a 6-month period.

METHOD: Sixty-one obese patients (BMI >30, <40 kg/m2), aged 18-65 years were evaluated. In the first phase of the study (30 days), the patients were given a placebo. We monitored compliance with a low-calorie diet (1200 kcal/day) and to the placebo. In the next stage, the double-blind phase (6 months), we compared placebo and sibutramine (10 mg/day). The criteria for evaluating efficacy were weight loss, reduction in body mass index (BMI), and abdominal and hip circumferences. Tolerability was assessed based on reported side effects, variation in arterial blood pressure and heart rate, metabolic profile (fasting glucose, total cholesterol and its fractions, and triglycerides), laboratory tests (renal and hepatic functions), and flow Doppler echocardiogram.

RESULTS: We observed a greater weight loss $(7.3 \mathrm{~kg}, 8 \% \mathrm{vs} 2.6 \mathrm{~kg}, 2.8 \%)$ and a reduction in body mass index $(7.4 \% \mathrm{vs}$ $2.1 \%$ ) in the sibutramine group than in the placebo group. Classifying the patients into 4 subgroups according to weight loss (weight gain, loss $<5 \%$, loss of $5 \%$ to $9.9 \%$, and loss $>10 \%$ ), we observed a weight loss of $>5 \%$ in $40 \%$ of the patients on sibutramine compared with $12.9 \%$ in the placebo group. We also detected weight gain in $45.2 \%$ of the placebo group compared to $20 \%$ in the sibutramine group. The sibutramine group showed improvement in HDL- cholesterol values (increased by $17 \%$ ) and triglyceride values (decreased by $12.8 \%$ ). This group also showed an increase in systolic blood pressure (6.7\%, $5 \mathrm{mmHg}$ ). There were no changes in echocardiograms comparing the beginning and end of follow-up, and side effects did not lead to discontinuation of treatment.

DISCUSSION: Sibutramine proved to be effective for weight loss providing an $8 \%$ loss of the initial weight. Compliance to prolonged treatment was good, and side effects did not result in discontinuation of treatment. These data confirmed the good efficacy, tolerability, and safety profiles of sibutramine for treatment of obesity.

DESCRIPTORS: Obesity. Weight loss. Sibutramine.

Prevalence of obesity and its comorbidities has increased all over the world $^{1-3}$. Abdominal or visceral obesity is closely related to hypertension, glucose intolerance, hypertriglyceridemia with low HDL levels, and hyperinsulinemia, resulting in the so-called "metabolic syndrome" with an increased risk of cardiovascular disease $e^{4-7}$. Obesity is also a risk factor for sleep apnea, orthopedic, dermatological and thromboembo- lic conditions, and some types of can$\operatorname{cer}^{8-9}$. In addition, excessive weight is a discriminating factor in the workplace and in society as a whole.

Today there is strong evidence that weight loss in overweight and obese

From the Department of Endocrinology and Metabolic Disorders, Hospital das Clínicas, Faculty of Medicine, University of São Paulo. subjects reduces cardiovascular risk factors ${ }^{10}$. Weight loss may be achieved through low-calorie diet, physical exercise, medication, and surgery, or as a combination of this management ${ }^{11-12}$. Drug treatment, associated with changes in dietary habits and physical exercise, has been shown to be effective, increasing compliance to treatment and resulting in satisfactory weight loss. 
Sibutramine is a tertiary amine initially developed as an antidepressant medication. Subsequent studies showed a significant effect of the drug on weight loss due to its satietogenic and calorigenic effects ${ }^{13-15}$.

The objective of the present study was to evaluate the efficacy, safety, and tolerability of sibutramine in obese patients over a 6-month period and to check the influence of the drug on the echocardiographic patterns of the patients. We considered effective weight loss to be a reduction by a minimum of $5 \%$ of the initial weight.

\section{PATIENTS AND METHODS}

From May 1998 to September 1999 we recruited 61 patients ( 60 female and 1 male), aged 18-65 years and with a body mass index $(\mathrm{BMI})>30 \mathrm{~kg} / \mathrm{m}^{2}$. The study was divided into 2 phases: the first phase (30 days) with the placebo, and the second phase ( 6 months) evaluating sibutramine $v s$ placebo.

The inclusion criteria were fasting glucose values $<130 \mathrm{mg} / \mathrm{dL}$, total cholesterol $<300 \mathrm{mg} / \mathrm{dL}$, triglycerides $<500$ $\mathrm{mg} / \mathrm{dL}$, uric acid $<8.0 \mathrm{mg} / \mathrm{dL}$, transamines $<40 \mathrm{mg} / \mathrm{dL}$, bilirubin $<2.0 \mathrm{mg} /$ $\mathrm{dL}$, urea $<40 \mathrm{mg} / \mathrm{dL}$, and creatine $<1.5$ $\mathrm{mg} / \mathrm{dL}$. Echocardiographic studies were also performed in this phase by means of a System Five, Ving Med, with color flow mapping able to generate and receive second harmonic echoes and synchronized firing of EKG. All echocardiographs were performed by the same observer (NH).

The exclusion criteria were weight loss in the previous 3 months, chronic diseases, such as renal or hepatic failure, endocrinopathy, cardiopathy, severe hypertension (systolic blood pressure $>150 \mathrm{mmHg}$, diastolic blood pressure $>110 \mathrm{mmHg}$ ), severe dyslipidemia (total cholesterol $>300 \mathrm{mg} / \mathrm{dL}$ and triglycerides $>500 \mathrm{mg} / \mathrm{dL}$ ), rheumatic, gastrointestinal, respiratory, neurological, and psychiatric disorders. Patients with an altered echocardiogram or taking beta-blockers, dopaminergic agonists, antidepressant agents, or thyroid hor- mones were also excluded. Women of childbearing age were instructed on how to use the appropriate contraceptive method.

In the first phase, the patients were clinically assessed and weighed (scale brand, Filizola) without shoes and wearing light clothes. Height was determined using a wooden stadiometer. BMI was calculated dividing weight $(\mathrm{kg})$ by height $\left(\mathrm{m}^{2}\right)$. Systolic and diastolic blood pressure levels were measured with patients in the seated position, on the left arm, and after a 5-minute rest period. ${ }^{16}$ The parameter used to measure the abdominal circumference was the shortest diameter between the lowest rib and the iliac crest of the subject in orthostatic position. In order to measure the hip circumference, the greater trochanter region was used ${ }^{17}$. During the first 30 days, the patients received placebo once a day (only the physicians had this information) at breakfast and were told to follow a low-calorie diet (1200 kcal/day) composed of 55\% carbohydrates, $30 \%$ fat, and $15 \%$ protein. They were also encouraged to practice 30-60 minutes of physical activity every day.

Thirty days later, the patients were randomized into 2 groups: one group received sibutramine $10 \mathrm{mg} /$ day and the other group received the placebo, to be taken at breakfast. The placebo tablets were obtained from Knoll Pharmaceutical Industries and were rigorously identical to the sibutramine tablets.

The patients were followed up for 6 months. During the monthly appointments, the efficacy criteria were reviewed: weight and height, abdominal and hip circumference, tolerability (variations in arterial blood pressure, and heart rate), and safety (possible adverse effects of the drug). Laboratory tests were repeated at months 4 and 6 , and an echocardiogram was repeated at the end of the study.

All patients signed the informed consent statement after being instructed about the study details, the Ethics Committee of the University Hospital approved the protocol.

The Student's $t$ test was used to compare means in the statistical analysis. To compare results from the initial and final phases, as well as different weight loss percentiles, we used the chi-square test. The significance level was $P<0.05^{18}$.

\section{RESULTS}

Out of 61 patients selected, 46 concluded the study. The mean age was 38.3 years for the sibutramine and placebo groups. The data for patients assessed during the first and last visits (height, weight, waist, and hip measures, BMI, systolic and diastolic blood pressure, heart rate, and laboratory tests) are presented in table 1 . The sibutramine and placebo groups had similar initial clinical and laboratory profiles.

Fifteen patients $(24.6 \%)$ withdrew treatment; 7 were in the sibutramine group $(7 / 30-23.3 \%)$, and 8 in the placebo group ( $8 / 31-25.8 \%)$. Dropout from study was not a result of side effects of the drug.

In the analysis of efficacy, the percentage reduction in weight $(8 \%)$ and BMI $(7.4 \%)$ was greater in the sibutramine group than in the placebo group (2.8\% and $2.1 \%$, respectively). The sibutramine group lost an average of $7.3 \mathrm{~kg} v s 2.6 \mathrm{~kg}$ in the placebo group. Reduction in BMI was the only statistically significant variable $(P<0.002)$.

Classifying weight loss into 4 subgroups (weight gain, loss $<5 \%$, loss of $5 \%$ to $9.9 \%$, and loss $>10 \%$ ), we observed a weight loss of $>5 \%$ in $40 \%$ of the patients from the sibutramine group as compared to $12.9 \%$ in the placebo group. On the other hand, $45.2 \%$ of the patients gained weight in the placebo group as compared with $20 \%$ in the sibutramine group (Table 2). Although the sibutramine group had better results than placebo group, these differences were not statistically significant, except in the weight gain group.

The abdominal circumference (AC) and hip circumference (HC) values showed a reduction of $7 \%$ (mean of $7.3 \mathrm{~cm})$ and $5 \%(6.2 \mathrm{~cm})$, respectively 
Table 1- Distribution of main variable means at the beginning and end of the study and variation observed during 6 months.

\begin{tabular}{|c|c|c|c|c|c|c|}
\hline \multirow[t]{2}{*}{ Variables } & \multicolumn{3}{|c|}{ Sibutramine } & \multicolumn{3}{|c|}{ Placebo } \\
\hline & $\begin{array}{c}\text { Initial } \\
(\mathrm{n}=30)\end{array}$ & $\begin{array}{l}\text { Final } \\
(\mathrm{n}=23)\end{array}$ & variation $/ \Delta \mathrm{P}^{*}$ & $\begin{array}{c}\text { Initial } \\
(\mathrm{n}=31)\end{array}$ & $\begin{array}{c}\text { Final } \\
(n=23)\end{array}$ & variation $/ \Delta \mathrm{P}$ \\
\hline Weight (kg) & 91.1 & 83.8 & $\downarrow 7.3(8.0 \%)$ & 91.5 & 88.9 & $\downarrow 2.6(2.8 \%)$ \\
\hline Height $(\mathrm{cm})$ & 157.8 & & & 157.4 & & \\
\hline Systolic blood pressure (mmHg) & 124.3 & 129.1 & $\uparrow 4.8(3.9 \%)$ & 129.3 & 134.4 & $\uparrow 5.1(3.9 \%)$ \\
\hline Diastolic blood pressure $(\mathrm{mmHg})$ & 79.1 & 84.4 & $\uparrow 5.3(6.7 \%)$ & 80.7 & 81.9 & $\uparrow 1.2(1.5 \%)$ \\
\hline Heart rate $(\mathrm{bpm})$ & 81.5 & 87.3 & $\uparrow 5.8(7.1 \%)$ & 82.6 & 86.8 & $\uparrow 4.2(5 \%)$ \\
\hline Abdominal $(\mathrm{cm})$ & 103.5 & 96.2 & $\downarrow 7.3(7.0 \%)$ & 104.8 & 101.5 & $\downarrow 3.3(3.1 \%)$ \\
\hline Hip (cm) & 122.4 & 116.2 & $\downarrow 6.2(5.0 \%)$ & 123.8 & 119.9 & $\downarrow 3.9(3.2 \%)$ \\
\hline BMI $\left(\mathrm{kg} / \mathrm{m}^{2}\right)^{* *}$ & 36.6 & 33.9 & $\Downarrow 2.7(7.4 \%)$ & 36.9 & 36.1 & $\downarrow 0.8(2.1 \%)$ \\
\hline Total-Cholesterol (mg/dL) & 218.9 & 221.7 & $\uparrow 2.8(1.2 \%)$ & 213.8 & 211.9 & $\downarrow 1.9(0.8 \%)$ \\
\hline HDL-C (mg/dL) & 43.9 & 51.5 & $\downarrow 7.6(17.3 \%)$ & 47.3 & 47.1 & \\
\hline LDL-C (mg/dL) & 147.1 & 147.2 & & 141.0 & 138.1 & $\downarrow 2.9(2 \%)$ \\
\hline Triglycerides (mg/dL) & 141.6 & 123.4 & $\downarrow 18.2(12.8 \%)$ & 113.3 & 126.6 & $\uparrow 13.3(11.7 \%)$ \\
\hline Glucose $(\mathrm{mg} / \mathrm{dL})$ & 99.8 & 98.7 & & 99.4 & 99.5 & \\
\hline
\end{tabular}

$* \Delta \mathrm{P}-$ percentage difference.

$* *$ The initial and final BMI was the only variable that the difference was statistically significant $(P<0.002)$.

Table 2 -Comparative analysis of sibutramine and placebo by weight loss Subgroups.

\begin{tabular}{lcc}
\hline & $\begin{array}{c}\text { Sibutramine } \\
\text { Number of patients/\% }\end{array}$ & $\begin{array}{c}\text { Placebo } \\
\text { Number of patients/\% }\end{array}$ \\
\hline Weight gain & $6(20 \%) *$ & $14(45.2 \%)$ \\
Loss $<5 \%$ & $12(40 \%)$ & $13(41.9 \%)$ \\
Loss $>5 \%-<10 \%$ & $4(13.3 \%)$ & $3(9.7 \%)$ \\
Loss $>10 \%$ & $8(26.7 \%)$ & $1(3.2 \%)$ \\
\hline
\end{tabular}

*The chi-square test showed statistically significant difference in weight gain subgroups $(P<0.03)$.

Table 3 - Proportion of patients who experienced adverse effects during the 6-month follow-up.

\begin{tabular}{lcc}
\hline Adverse effects & Sibutramine group (30) & Placebo group (31) \\
\hline Intestinal constipation & $2(6.6 \%)$ & $5(16.1 \%)$ \\
Dry mouth & $2(6.6 \%)$ & $4(12.9 \%)$ \\
Epigastralgia & 0 & $1(3.2 \%)$ \\
Somnolence & $1(3.3 \%)$ & 0 \\
\hline
\end{tabular}

Although the placebo group reported more adverse effects, there was no statistically significant difference between the two groups $(P>0.05)$.

in the sibutramine group, and there was a reduction of $3 \%(3.5 \mathrm{~cm})$ in both values in the placebo group (Table 1). These differences in both groups were not statistically significant.

Regarding blood pressure, we observed increased systolic pressure values in both groups and with the same variation $(5 \mathrm{mmHg})$. Diastolic pressure, however, increased only in the sibutramine group $(5 \mathrm{mmHg})$. Concerning the lipid profile (total cholesterol and LDL-cholesterol) and glucose levels, the values remained unaltered in both groups. There was an improvement in HDL-cholesterol (increase of $17 \%$ ) and triglyceride levels (decrease of $12.8 \%$ ) in the group treated with sibutramine (Table 1). There was no statistically significant difference between these variables between sibutramine and placebo groups.

Tolerability and safety results revealed that 5 patients in the sibutramine group and 10 patients in the placebo group reported side effects. None of them discontinued treatment because of side effects. The most common side effects were intestinal constipation and dry mouth. Despite the higher incidence of side effects in the placebo group, there was no statistically significant difference between the groups $(P>0.05)$ table 3 .

In the initial assessment of 61 patients, $40(65.5 \%)$ of them had a normal echocardiogram, and 21 patients showed slight alterations with no hemodynamic impact (Table 4). Six months later, there was no alteration in the echocardiographic patterns in either group.

\section{DISCUSSION}

Obesity is an important risk factor for morbidity and mortality. There is evidence that weight loss leads to reduced risk of morbidity and mortality.

In the obese patients assessed in this study, the administration of sibutramine resulted in better results than administration of placebo in patients undergoing diet restriction and exercise programs (weight loss: $8 \% \mathrm{vs}$ $2.8 \%$; reduction in BMI: $7.4 \%$ vs $2.1 \%$; reduction in waist measure: $7 \%$ vs $3.1 \%$ ). However, only the difference in BMI 
Table 4- Analysis of echocardiographic results of patients before the study and at the end of the 6-month test period.

\begin{tabular}{lcc}
\hline $\begin{array}{l}\text { Alterations found in the } \\
\text { first echocardiogram }\end{array}$ & $\begin{array}{c}\text { Number of } \\
\text { patient/frequency }\end{array}$ & $\begin{array}{c}\text { Echocardiogram at the } \\
\text { end of the study (6 months) }\end{array}$ \\
\hline Normal & $40(65.5 \%)$ & Unaltered \\
Mild valve thickening & $4(6.5 \%)$ & Unaltered \\
Mild valvular regurgitation & $8(13.1 \%)$ & Unaltered \\
Altered LV compliance & $4(6.5 \%)$ & Unaltered \\
Mild valve thickening and & $5(8.2 \%)$ & Unaltered \\
regurgitation & & \\
\hline
\end{tabular}

was statistically significant. In addition, the percentage of subjects who lost $>5 \%$ of their initial weight was markedly higher in the sibutramine group ( $40 \%$ vs $12.9 \%$ in the placebo group).

It should be emphasized that weight loss $35 \%$ results in evident reduction in cardiovascular risks. In the patients who did not have a marked metabolic risk profile, we observed increased HDL levels and reduced triglyceride levels with the use of sibutramine.

Regarding tolerability, there was no statistically significant difference between the two groups; side effects were not severe, and no patient discontinued treatment because of adverse effects.
The slight increase in systolic blood pressure $(5 \mathrm{mmHg})$ and in diastolic blood pressure $(5 \mathrm{mmHg})$ in the sibutramine group was corroborated by the literature ${ }^{13-15}$. The slight increase in blood pressure seems to be compensated by drug-induced weight loss ${ }^{15}$. It is also important to mention that increased systolic blood pressure was observed in the placebo group, but there was no explanation for this fact.

We were particularly interested in checking whether sibutramine would cause valvular echocardiographic alterations, as described in studies with fenfluramine and D-fenfluramine ${ }^{21}$. The echocardiographic study was very de- tailed and was carried out with sophisticated equipment. The analysis of findings was made by the same observer. Out of 61 patients, 21 had some previous echocardiographic alteration, showing that heart disease may be demonstrated in a significant percentage of apparently healthy obese patients. However, in the final assessment, we did not identify any alterations in the echocardiogram in either group. These data were similar to those found in another study ${ }^{22}$, demonstrating that sibutramine does not have a dilation effect on the heart.

Therefore, our results enabled us to conclude that sibutramine is an effective drug for inducing reduction of the body mass index and for preventing weight gain in obese patients undergoing low-calorie diet and exercise programs, and it has good safety and tolerability profiles.

\section{ACKNOWLEDGEMENTS}

The present study was supported by Knoll Pharmaceutical Industries Brazil. 
HALPERN A e col. - Avaliação da eficácia, segurança e tolerabilidade da sibutramina em obesos - estudo randomizado duplo-cego. Rev. Hosp. Clín. Fac. Med. S. Paulo 57(3): 2002.

O presente estudo objetivou comparar a eficácia, segurança e tolerabilidade da sibutramina em pacientes obesos.

MÉTODO: Selecionamos 61 pacientes obesos $\left(30<\mathrm{IMC}<40 \mathrm{~kg} / \mathrm{m}^{2}\right)$ entre 18 65 anos. Na primeira fase do estudo (30 dias), os pacientes usaram medicação placebo e realizaram os exames de inclusão, enquanto acompanhamos a adesão à dieta hipocalórica prescrita (1200cal/dia) e à medicação. A seguir, na fase duplo-cega (6 meses), comparamos placebo vs sibutramina (10mg/dia). Os critérios para a avaliação da eficácia foram: perda de peso, diminuição do ín- dice de massa corpórea (IMC), circunferência abdominal e de quadril. A avaliação da tolerabilidade foi feita pelo relato dos efeitos adversos, variações da pressão arterial, frequiência cardíaca, perfil metabólico (glicemia de jejum, colesterol total e frações e triglicerídeos), alterações laboratoriais (função hepática e renal) e pelo ecocardiograma com Doppler fluxo realizado em todos os pacientes no início e fim do tratamento.

RESULTADOS: Houve uma diminuição maior de peso $(7,3 \mathrm{~kg}-8 \%$ vs $2,6 \mathrm{~kg}$ $2,8 \%)$ e IMC $(7,4 \%$ vs $2,1 \%)$ no grupo sibutramina do que no grupo placebo. Quando dividimos a perda de peso em quatro subgrupos (aumento de peso, perda $<5 \%$, perda entre $5-9,9 \%$, perda $>10 \%$ ) ocorreu perda de peso $>5 \%$ em $40 \%$ dos pacientes em uso da sibutramina vs $12,9 \%$ no grupo placebo e ganho de peso em $45,2 \%$ dos pacientes em uso de placebo vs $20 \%$ no grupo sibutramina.
No grupo sibutramina notamos melhora dos níveis de HDL-colesterol (aumento de $17 \%$ ) e triglicerídeos (diminuição de $12,8 \%$ ), neste grupo ocorreu também um aumento da pressão arterial sistólica (6,7\%-5mmHg). Não houve alteração entre os ecocardiogramas do início e final do acompanhamento e os efeitos adversos não levaram à descontinuação do tratamento.

DISCUSSÃO: A sibutramina mostrou-se eficaz na redução de peso, proporcionando um perda de $8 \%$ em relação ao peso inicial. Houve boa adesão do paciente ao tratamento prolongado, sem haver descontinuações pelos efeitos adversos. Estes dados confirmam o bom perfil de eficácia, tolerabilidade, e segurança da sibutramina no tratamento da obesidade.

DESCRIPTORS: Obesidade. Perda de peso. Sibutramina.

\section{REFERENCES}

1.HODGE AM \& ZIMMET PZ - The epidemiology of obesity. Clin Endocrinol Metab 1994; 8:577-99.

2.SEIDELL JC - The worldwide epidemic of obesity. In: GUY-GRAND B; AILHAUD G. eds. - Progress in obesity research, $8^{\text {th }}$ ed, London, John Libbey, 1999. p. 661-68.

3.WHO- Obesity: preventing and managing the global epidemic. Report of a WHO consultation on obesity. Geneva, June 3-5, 1997. Geneva: WHO, 1998.

4.KISSEBACH AH, VYDELINGUM N, MURRAY RW et al. - Relation of body fat distribution to metabolic complications of obesity. $\mathbf{J}$ Clin Endocrinol Metab 1982; 54:254-60.

5.LAPIDUS L, BENGTSSON C, LARSSON B et al. - Distribution of adipose tissue and risk of cardiovascular disease and death: a 12year follow-up of participants in the population study of women in Gothenburg, Sweden. Br Med J 1984; 289:1261-3.

6.HUBERT H B, FEINLIEB M, MCNAMARA PM et al. - Obesity as an independent risk factor for cardiovascular disease: a 26-year follow-up of participants in the Framingham Heart Study. Circulation 1983; 67:5-14

7.LARSSON B, SVARSUDD K, WELIN L et al. - Abdominal adipose tissue distribution, obesity and risk of cardiovascular disease and death: 13-year follow-up participants in the study of men born in 1913. Br Med J 1984; 288:1401-4.

8.MANCINI M C, ALOE F \& TAVARES S - Apnéia do sono em obesos. Arq Bras Metab 2000; 4(1):81-90.

9.HALPERN A, MAT OS AFG, SUPLICY HL et al. - Obesidade. São Paulo, Lemos Ed, 1998. p. 191-197.

10.GOLDSTEIN DJ - Beneficial health effects of modest weight loss. Int J Obes Relat Met Dis 1992; 16:397-415.

11.NATIONAL Task Force on the Prevention and Treatment of Obesity. Long term pharmacotherapy in the management of obesity. JAMA 1996; 276:1907-5.
12.REPORT of a WHO Consultation on Obesity - Preventing and managing the global epidemic. Geneva: World Health Organization, 1997.

13.HANSEN DL,TOUBRO S, STOCK MJ et al. - The effect of sibutramine on energy expenditure and appetite during chronic treatment without dietary restriction. Int J Obesity 1999; 23:1016-24.

14.BRAY GA, BLACKBURN GL, FERGUSON JM et al. - Sibutramine produces dose-related weight loss. Obesity Res 1999; 7:189-98.

15.JAMES WPT, ASTRUP A, FINER N et al. - Effect of sibutramine on weight maintenance after weight loss: a randomized trial. Lancet 2000; 356:2119-2125.

16.PERLOFF D, GRIM C \& FLACK J - Human blood pressure determination by sphygmomanometry. Circulation 1993; 88:2460-7.

17.LOHMAN TG, ROCHE AF \& MART ORELLI R Anthropometric Standardization Reference Manual. Champaign, IL, Human Kinetics 1998. p. 90.

18.ARMIT AGE P \& BERRY G - Statistical methods in medical research, $2^{\text {nd }}$ ed. Oxford, Blackwell, 1987. p. 282-95.

19.LAVIE CJ \& MESSERLIF H - Cardiovascular adaptation to obesity and hypertension. Chest 1986; 90(2):275-9.

20.KU C S, LIN S L, WANGD J et al. - Left ventricular filling in young normotensive obese adults. Am J Cardiol 1994; 73:613-5.

21.CONNOLLY H M, CRARY J L, MC GOON M D et al. - Valvular heart disease associated with fenfluramine - phentermine. $\mathbf{N}$ Engl J Med 1997; 337:581-8.

22.BACH DS, RISSAMEN AM \& MENDEL CM - Absence of cardiac valve dysfunction in obese patients treated with sibutramine. Obes Res 1999; 7:363-9.

Received for publication on August 21, 2001. 